\title{
Protecting intellectual property in foreign subsidiaries: An internal network defense perspective
}

\author{
Yan Yan ${ }^{1}$, Jiatao $\mathrm{Li}^{2}$ and \\ jingjing Zhang ${ }^{3}$
}

${ }^{1}$ School of Business, Renmin University of China, Beijing 100872, China; ${ }^{2}$ Department of Management, Hong Kong University of Science and Technology, Clear Water Bay, Hong Kong; ${ }^{3}$ School of Public Policy and Management, University of Chinese Academy of Sciences, Beijing 100049, China

Correspondence:

J Zhang, School of Public Policy and Management, University of Chinese Academy of Sciences, Beijing 100049, China e-mail: zhangjingjing@ucas.ac.cn

\begin{abstract}
This study examines firm internal network structures as a defense of intellectual property rights (IPR) in high-risk environments with inadequate IPR protection. Specifically, we investigate firm social and knowledge-based network structures individually. A foreign subsidiary can intensify social complexity by strengthening the small-worldness in its collaboration networks and attenuate knowledge-relatedness by decreasing the small-worldness in its knowledge networks. In a subsidiary, the effectiveness of these measures depends to some extent on the parent firm's experience in the host country. Longitudinal data on 401 foreign subsidiaries in the pharmaceutical industry from 1980 to 2017 have been analyzed in a quasi-experiment using difference-in-differences and two-stage regression. The results provide empirical support for these ideas. Findings highlight the explanatory power of internal network structures when discussing knowledge protection and show the utility of taking an internal network defense perspective in examining IPR protection.
\end{abstract}

Journal of International Business Studies (2022) 53, 1924-1944.

https://doi.org//0.1057/s41267-021-00430-5

Keywords: network theory; intellectual property; subsidiaries; internal networks; smallworldness; pharmaceuticals

The online version of this article is available Open Access

\section{INTRODUCTION}

Multinational enterprises (MNES) have experienced an increased internationalization in their innovative activities (Li \& Xie, 2011; Meyer \& Peng, 2016). However, a foreign subsidiary may risk exposing its knowledge to local competitors when the host location does not offer strong protection for intellectual property rights (IPR) (Berry, 2017; Li \& Xie, 2016). Scholars have long studied the defenses that foreign subsidiaries can adopt to protect their innovations from appropriation. One research stream suggests that a foreign subsidiary may use external relationships to substitute for inadequate local institutions (Chen et al., 2018; Choi \& Contractor, 2016). Studies of this literature have adopted a network perspective
Received: 6 January 2020

Revised: 21 January 2021

Accepted: 1 March 2021

Online publication date: 7 May 2021 
and found that firms might change their external network composition and structure for knowledge protection (Balachandran \& Hernandez, 2016; Hernandez \& Menon, 2019).

Another research stream has focused on IPR protection mechanisms within a foreign subsidiary (Buckley \& Casson, 2009; Li \& Xie, 2016). Examples are dedicated employee management (Inkpen et al., 2019) and technological knowledge management (Pisani \& Ricart, 2018). However, international business (IB) studies on harnessing internal networks for knowledge protection remain relatively few (Kleinbaum \& Stuart, 2014).

The internal network perspective deserves adequate scholarly attention in light of Inkpen et al.'s (2019) assertion that knowledge leakage is unavoidable due to the social networks to which individuals belong. Within a firm, the search process in innovation, imitation, or appropriation is usually network-based rather than isolated or dyadic (Ahuja, 2000). Therefore, the network structure perspective may provide additional power in explaining knowledge protection (Athreye et al., 2016; Inkpen et al., 2019). This perspective indicates that internal network defenses can prevent misappropriation and may be particularly relevant for a foreign subsidiary. On this basis, this study explores the role of internal network structure in protecting a foreign subsidiary's innovation from appropriation.

Internal networks take many forms (Alcácer \& Zhao, 2012; Wang et al., 2014). This study focuses on socially-based internal collaboration networks (ICNs) and knowledge-based internal knowledge networks (IKNs) in foreign subsidiaries. ICNs are sets of individuals characterized by collaborative ties (Tsai, 2001). Here, ICNs refer to networks of patenting researchers within a firm. An ICN "node" is an inventor, and a "tie" is a collaboration between two inventors.

IKNs are networks made up of elements in a firm's knowledge base and the linkages between those elements. The knowledge elements typically include "...tentative conclusions on facts, theories, methods, or procedures about a subject matter by the research community of a scientific or technological field" (Wang et al., 2014: 487). A concept, theory, method, or axiom is an example of a knowledge element (Wang et al., 2014). An IKN "node" is a technology class, and a "tie" is a prior successful combination of technology from two classes - specifically, for this study, in a patent (refer to Figures 2 and 3 in Appendix 1). We expect that, in countries where IPR protection is weak, a foreign subsidiary can raise barriers to imitation by suitably arranging the structures of its two types of internal networks.

We focus on one macro-structural property of an internal network: small-worldness. "Small-world" originates from a famous experiment (Milgram, 1967) that showed "six degrees of separation." As defined by Watts and Strogatz (1998), "...the systems can be highly clustered, like regular lattices, yet have small characteristic path lengths, like random graphs, can be called 'small-world' networks, by analogy with the small-world phenomenon." Given that a small-world structure affects the knowledge search and transfer efficiency (Phelps et al., 2012), it may have significant implications for firm knowledge protection.

We test whether the two internal networks' small-worldness can substitute for an inadequate external environment in various ways through different mechanisms. First, knowledge workers inscrutably belong to complex social relationships. The ICN complex small-world structure can result in social complexity (Amaral et al., 2000; Newman et al., 2002), hindering other firms' socially-based search efforts to interpret and imitate its activities. A foreign subsidiary can build its ICN with high small-worldness to prevent its knowledge from leaking to others. Second, learning is generally inter-related (Cohen \& Levinthal, 1990). A foreign subsidiary prefers to reduce IKN's small-worldness to decrease its knowledge-relatedness and increase imitators' difficulties in deciphering its core knowledge. A subsidiary's propensity to use internal network techniques to defend its IP also hinges on the extent to which the MNE has locallyapplicable knowledge and capabilities. An MNE's host-country experience tends to weaken its subsidiaries' dependence on internal networks to protect its IP.

The novel contributions of this study are as follows. We add an internal network structure perspective to the literature about how a foreign subsidiary responds to risks from weak IP regimes. The defensive utility of the external network structure has gathered considerable attention from management scholars. Yet, the role of internal networks in knowledge misappropriation, and protection remains underexplored. Then, we deem the internal network structure helpful because even firms with similar inventor portfolios and knowledge bases may organize them differently. Here, we consider small-worldness a protective device, 
addressing a critical gap in the field. Finally, we focus on two internal networks, indicating that two different mechanisms can explain how the smallworldness of ICNs and IKNs affects knowledge appropriation risks.

Given that the foreign subsidiaries of an MNE may face markedly different institutional environments, we also extend the understanding of effective tools for defending IPR in a weak institutional environment at the subsidiary level. Beyond an MNE's characteristics, we examine subsidiaries to test whether network structure heterogeneity inside a subsidiary responds to its risk exposure in a weak IPR environment.

Using foreign subsidiaries of American pharmaceutical companies between 1980 and 2017 as an empirical context, we conduct a quasi-natural experiment and two-stage least squares (2SLS) estimation to examine our propositions.

\section{THEORETICAL FRAMEWORK AND HYPOTHESES}

\section{Theoretical Background}

Weak IPR protection in a host country increases a foreign subsidiary's proprietary knowledge leakage risks. A foreign subsidiary's ability to protect its parent's (and its) knowledge in an environment with weak IPR protection is critical for its innovation and competitive advantages (Feinberg \& Gupta, 2009; Li \& Xie, 2011, 2016). Table 1 summarizes ten recent IB studies of knowledge protection in a weak institutional environment ${ }^{1}$.

Considerable work has shed light on how MNEs and their subsidiaries protect their innovation from imitation using the external relationship perspective. Scholars have suggested that MNEs can forge political ties to minimize institutional costs (Faccio, 2006; Joel \& Oliver, 1991; Siegel, 2007). MNEs can also establish alliances with local brokers and highstatus global firms (Shi et al., 2014) or occupy superior positions in different alliance networks (Iurkov \& Benito, 2018). In terms of technology transfer, some scholars have shown that, in a weak IPR country, a foreign subsidiary could reduce imitation risks by controlling technology transfer to local firms through, for example, erecting barriers and grabbing market shares (Bosworth \& Yang, 2000; Sun et al., 2010).

Employee mobility can be a major source of leaks. Scholars recommend developing a reputation for IP toughness (Agarwal et al., 2009) to discourage misconduct. For example, in 2018, Google sued one of its former engineers for stealing self-driving car trade secrets to help Uber. The engineer was eventually fined USD 179 million and given an 18-month jail sentence.

Some of the selected studies in Table 1 emphasize the critical role of subsidiaries' outside relationships (e.g., with the parent firm, sister firms, or other firms) in protecting their knowledge (Berry, 2017; Choi \& Contractor, 2016; Dang et al., 2020; Du \& Williams, 2017; Gooris \& Peeters, 2016; Ivus et al., 2017). Those who recognized a role for external relationships (Ryu et al., 2018) have adopted an external network perspective in their work (Balachandran \& Hernandez, 2016; Hernandez \& Menon, 2019; Zhelyazkov, 2018). Others have emphasized internal mechanisms, such as employee management (Inkpen et al., 2019) and technology management (Pisani \& Ricart, 2018), to prevent knowledge spillover (Alnuaimi \& George, 2016; Baldwin \& Henkel, 2015; Flammer \& Kacperczyk, 2019; Kim, 2016; Nandkumar \& Srikanth, 2016).

However, scholars have yet to reach consensus on this topic. For example, Baldwin and Henkel (2015) argued that employing individuals with common values and beliefs can at the same time aggravate and mitigate knowledge expropriation risks. Alcácer and Zhao (2012) implied that strong knowledge linkages between clusters could protect proprietary knowledge. Baldwin and Henkel (2015) proposed that dispersing technology and separating knowledge into modules can minimize the possibility of expropriation. The above studies focused on the relational aspects of internal linkages. The debates may arise from a lack of attention to their structural aspects, although several scholars have emphasized that a network perspective should be applied (Kleinbaum \& Stuart, 2014; Kurt \& Kurt, 2020; Wang et al., 2014).

Internalization research has extensively investigated internal units and dyadic relationships but not the patterns and the structure of interaction between internal units (Kurt \& Kurt, 2020). It has shed some light on protection mechanisms from an internal networks perspective, but it has not dealt with the structural properties of firms' internal networks in any detail. As asserted by Kleinbaum and Stuart (2014: 354), “...very little of it has explored the consequences of intraorganizational network structure for the firm itself." The current study addresses this gap by exploring the roles of 
Table 1 IB studies of knowledge protection in a weak institutional environment

\begin{tabular}{|c|c|c|c|c|c|}
\hline No. & $\begin{array}{l}\text { Authors, } \\
\text { journal }\end{array}$ & $\begin{array}{l}\text { Independent } \\
\text { variables }\end{array}$ & Dependent variables & Key findings & $\begin{array}{l}\text { The focus of the } \\
\text { protection } \\
\text { mechanism }\end{array}$ \\
\hline 1 & $\begin{array}{l}\text { Berry } \\
(2017), \\
\text { JIBS }\end{array}$ & IPR; expatriates & $\begin{array}{l}\text { Knowledge value and } \\
\text { transfer }\end{array}$ & $\begin{array}{l}\text { Home-country expatriates can better } \\
\text { protect the transfer of parent firm } \\
\text { knowledge to foreign subsidiaries in } \\
\text { countries with weak IPR. }\end{array}$ & $\begin{array}{l}\text { A parent firm's } \\
\text { relationships with } \\
\text { foreign subsidiaries }\end{array}$ \\
\hline 2 & $\begin{array}{l}\text { Berry } \\
(2020), \\
\text { JIBS }\end{array}$ & $\begin{array}{l}\text { Knowledge } \\
\text { activity overlap } \\
\text { with home and } \\
\text { foreign rivals }\end{array}$ & $\begin{array}{l}\text { The number of } \\
\text { countries to which } \\
\text { innovation has been } \\
\text { transferred }\end{array}$ & $\begin{array}{l}\text { Knowledge threats from rivals can lead to a } \\
\text { firm's transferring innovations to foreign } \\
\text { countries. }\end{array}$ & $\begin{array}{l}\text { The management of } \\
\text { technological } \\
\text { knowledge }\end{array}$ \\
\hline 3 & $\begin{array}{l}\text { Choi \& } \\
\text { Contractor } \\
(2016) \\
\text { JIBS }\end{array}$ & $\begin{array}{l}\text { Economic, } \\
\text { institutional, and } \\
\text { cultural factors }\end{array}$ & $\begin{array}{l}\text { Alliance governance } \\
\text { modes }\end{array}$ & $\begin{array}{l}\text { The difference between alliance partners is } \\
\text { the determinant of the governance choice. } \\
\text { When the rule-of-law is weak, firms are } \\
\text { likely to use more integrated modes. }\end{array}$ & $\begin{array}{l}\text { The design of external } \\
\text { relationships }\end{array}$ \\
\hline 4 & $\begin{array}{l}\text { Dang et al. } \\
(2020) \text {, } \\
\text { JWB }\end{array}$ & - & - & $\begin{array}{l}\text { MNEs in Vietnam used the following risk } \\
\text { mitigation approaches: managing } \\
\text { alertness, portraying good behavior, } \\
\text { navigating the state of comfort, and active } \\
\text { mediation. }\end{array}$ & $\begin{array}{l}\text { Relationships with } \\
\text { local government and } \\
\text { other stakeholders }\end{array}$ \\
\hline 5 & $\begin{array}{l}\text { Du \& } \\
\text { Williams } \\
\text { (2017), JIM }\end{array}$ & - & - & $\begin{array}{l}\text { The weaker the institutional context, the } \\
\text { more helpful would be inter-organizational } \\
\text { trust through relational contracting. }\end{array}$ & $\begin{array}{l}\text { MNE subsidiaries' } \\
\text { inter-organizational } \\
\text { trust with the local } \\
\text { partners. }\end{array}$ \\
\hline 6 & $\begin{array}{l}\text { Gooris \& } \\
\text { Peeters } \\
(2016) \\
\text { JIBS }\end{array}$ & $\begin{array}{l}\text { The lack of legal } \\
\text { protection in the } \\
\text { host country }\end{array}$ & $\begin{array}{l}\text { Process } \\
\text { fragmentation }\end{array}$ & $\begin{array}{l}\text { MNEs are likely to disperse processes } \\
\text { among multiple foreign units when the } \\
\text { host-country institutions offer weak IPR } \\
\text { protection. }\end{array}$ & $\begin{array}{l}\text { The distribution of } \\
\text { activities across units }\end{array}$ \\
\hline 7 & $\begin{array}{l}\text { Inkpen } \\
\text { et al. } \\
\text { (2019), } \\
\text { JIBS }\end{array}$ & - & - & $\begin{array}{l}\text { Knowledge leaks from MNEs happen } \\
\text { naturally due to inter-firm relationships, } \\
\text { interactions and socialization, and } \\
\text { employee mobility. }\end{array}$ & $\begin{array}{l}\text { Interfirm relationships } \\
\text { and employee } \\
\text { management }\end{array}$ \\
\hline 8 & $\begin{array}{l}\text { Ivus et al. } \\
(2017) \\
\text { JIBS }\end{array}$ & $\begin{array}{l}\text { The strength of } \\
\text { patent protection }\end{array}$ & $\begin{array}{l}\text { The level of } \\
\text { unaffiliated or } \\
\text { affiliated licensing }\end{array}$ & $\begin{array}{l}\text { Strong IPR protection in the host country } \\
\text { increases the possibility of licensing } \\
\text { innovations to unaffiliated parties. }\end{array}$ & $\begin{array}{l}\text { The relationships with } \\
\text { unaffiliated and } \\
\text { affiliated parties }\end{array}$ \\
\hline 9 & $\begin{array}{l}\text { Kurt \& Kurt } \\
(2020), \text { IBR }\end{array}$ & - & - & $\begin{array}{l}\text { Interpersonal networks' informal } \\
\text { constraints can be effective safeguards } \\
\text { against opportunism. Understanding social } \\
\text { networks requires a systematic analysis of } \\
\text { their structure. }\end{array}$ & $\begin{array}{l}\text { The social network } \\
\text { perspective }\end{array}$ \\
\hline 10 & $\begin{array}{l}\text { Pisani \& } \\
\text { Ricart } \\
\text { (2018) MIR }\end{array}$ & $\begin{array}{l}\text { Formal and } \\
\text { informal } \\
\text { institutions }\end{array}$ & $\begin{array}{l}\text { Augmenting home- } \\
\text { based knowledge } \\
\text { with offshore } \\
\text { innovation }\end{array}$ & $\begin{array}{l}\text { Formal and informal institutions have } \\
\text { different effects on strategic decisions } \\
\text { about offshore innovation. The stronger the } \\
\text { host country's IPR protection, the more } \\
\text { possibility that a developed-country } \\
\text { multinational enterprise offshores } \\
\text { innovation aimed at augmenting home- } \\
\text { based knowledge. }\end{array}$ & $\begin{array}{l}\text { The management of } \\
\text { technological } \\
\text { knowledge }\end{array}$ \\
\hline
\end{tabular}

Journals: Journal of International Business Studies (JIBS); Journal of World Business (JWB); Journal of International Management (JIM); International Business Review (IBR); Management International Review (MIR).

internal network structures in IPR protection in subsidiaries.
Pharmaceutical Industry

Pharmaceutical firms are often involved in global drug development and commercialization. Most large pharmaceutical firms operate worldwide, 
including emerging economies with possibly low IPR security, and often distribute their new-drug testing activities across multiple countries (Gooris $\&$ Peeters, 2016). Some of these firms facilitate product distribution by building $R \& D$ laboratories overseas for low-cost access to high-quality employees (Zhao, 2006). MNEs' globalization of R\&D can utilize their existing capabilities and develop new knowledge in exploring foreign markets (Song \& Shin, 2008). Many R\&D subsidiaries have become centers of excellence, building local technological competence suitable for the local innovation environment (Yamin \& Otto, 2004). However, international operations may expose pharmaceutical companies to intellectual property leakage risks.

The global pharmaceutical industry is innovation-intensive. The industry is heavily reliant on research and development, and reinvests much of its net revenue back into innovation $(17 \%$ on average in 2019, according to Investopedia ${ }^{2}$ ). Approximately $82 \%$ of patentable inventions in pharmaceuticals are patented (Qian, 2007). Moreover, the innovation process in this industry is tightly regulated and highly structured. Most governments around the world have established their own pharmaceutical regulatory body.

IP protection is critical in the pharmaceutical industry. The industry faces continuous IPR protection modifications because of its high $R \& D$ spending and the long time needed to bring a new drug to the market (De Carolis, 2003). Thus, the industry must rely heavily on IP protection because technological advancements can reduce the difficulty in duplicating chemical compounds (Ostergard, 2000). Also, a firm cannot sustain its competitive advantages if it cannot fully protect its technological competencies. However, some countries with strong IPR protection for other industries may not always provide strong pharmaceutical product protection (Liu \& La Croix, 2015; Qian, 2007). This situation reinforces the need for pharmaceutical firms to use more internal strategies to prevent knowledge leakage.

This study determines how a foreign subsidiary uses internal network defenses to prevent misappropriation in a weak IPR environment. Given that counterfactual outcomes of IPR protection within a country are difficult to observe, we use international comparisons as valuable leverage for testing hypotheses. The agreement on trade-related aspects of intellectual property rights (TRIPS) has emphasized patent protection for the pharmaceutical industry. The signing of such an agreement in many countries in the 1990s created a natural experiment useful for investigating the current research questions. On the basis of the above discussion, we consider the pharmaceutical industry suitable for this study.

\section{Theory and Hypothesis Development}

\section{Network perspective}

A network comprises a finite set of nodes individuals, organizations, or knowledge elements - and their relationships (Borgatti \& Halgin, 2011). The network perspective indicates that the patterns of relationships emphasized as the unit of analysis strongly influence the world and its actors (Marin \& Wellman, 2011).

The literature has applied a network perspective to examine various IB phenomena: internationalization (Yamin \& Kurt, 2018), MNEs (Iurkov \& Benito, 2018), and new international ventures (Coviello, 2006), to name a few. Some recent developments of network theory research have emphasized the increasing variety of the linkages exploited. An elaboration of that view asserts that innovation involves "double networks" and multiple embeddedness. In the current study, we apply a double network perspective to analyze internal social and knowledge-based networks.

We identify a link between two researchers on the basis of their co-authoring in one or more patents. An ICN emphasizes knowledge transfer through such social ties. In an IKN, the defining links are between scientific and technological knowledge elements (Yayavaram \& Ahuja, 2008). These two types of internal networks are not necessarily isomorphic (Wang et al., 2014), and the patterns of collaboration between inventors are generally different from those of links between knowledge elements. The same structural characteristic can have different meanings and effects in these two types of networks. For example, Wang et al. (2014) showed that centrality in a collaboration network indicates an actor's status, and centrality in a knowledge network indicates natural relatedness between a knowledge element and others.

Socially-based collaboration networks facilitate organizations' or individuals' resource access, information dissemination, and ideas and interaction (Kurt \& Kurt, 2020). Knowledge-based networks extend opportunities to combine knowledge elements (Wang et al., 2014). An ICN facilitates a socially-based search and has social ties that allow 
for knowledge sharing and searching among many inventors. An IKN facilitates a knowledge search for novel knowledge elements among inventors on the basis of knowledge-relatedness. Well-managed firms manage the shapes of their internal collaboration and knowledge networks.

\section{Small-worldness}

Rather than emphasizing the ego structure of the above two types of networks, we focus on the smallworldness of a network as a whole because smallworldness is surprisingly related to knowledge diffusion (Phelps et al., 2012; Schilling \& Phelps, 2007). A small-world network indicates close links between network members' immediate contacts (termed clusters) and those bridging clusters. Actors in small-world systems, such as researchers in a cluster of close research partners, can interact with others through relatively few intermediaries. At the same time, their cluster partners are likely to be in varying clusters with others. These connections help researchers communicate or be in touch with partners of their partners. Such a network exhibits two attributes of a small world: high local clustering and low global separation.

Small worlds arise in a wide range of settings, such as alliances (Gulati et al., 2012), scientific collaboration (Newman, 2001), and elite corporate networks (Davis et al., 2003). However, published IB studies of network small-worldness are rare. One exception is a report by Kogut and Walker (2001), who found that ownership links between German firms constitute a small world.

Two properties of small-worldness - clustering and average path - are related to information exchange and knowledge flow (Ellis, 2011; Iurkov \& Benito, 2018). The extant IB literature has discussed these relationships. Rugman and Verbeke (2003) argued that isolating mechanisms, such as causal ambiguity, are essential if outsiders cannot replicate a cluster's routines. Ellis (2011) argued that network distance between actors influences their propensity to recognize new opportunities. To sum up, existing IB research has recognized the roles of network clustering and average path in knowledge flow, but mainly from the perspective of performance. The role of small-worldness in knowledge protection has received little attention.

ICN and IKN small-worldness and IPR protection

Social relationships are complex, and a collaboration network is a real-world complex system (Amaral et al., 2000; Newman et al., 2002). These characteristics can be advantageous, because, when complex social relationships intertwine with the complex ICN small-world structure, outsiders will have difficulty imitating the resulting complexity. Colbert (2004) explained the arrangement of an organization's employees in a complex social system. Such a system is complicated for others to interpret and imitate, providing a competitive advantage (Clark \& Lengnick-Hall, 2012). This advantage should be particularly useful in a country with weak IPR protection.

Valuable knowledge extends beyond its procedural, substantive, and technical aspects to determine the most strategic place where knowledge should reside in a firm (Cohen \& Levinthal, 1990). This process relies on knowing who knows what and how they work together. A subsidiary social complexity makes that sort of knowledge extremely difficult to transfer, which reduces the risks of knowledge spillover to other firms in the host country. For example, when the social complexity is great, rivals will have difficulty imitating a valuable innovation by recruiting one or a few employees (Colbert, 2004). When R\&D workers are tightly linked in a local cluster, they tend to develop common norms, trust, and group sanctions in that local community. They only share information with a few strongly connected partners, making it harder for outsiders to access and obtain knowledge. In an interview in this study, a foreign subsidiary manager described most knowledge researchers as only cogs in a complex machine, so innovation rests on complex collaborations.

Hypothesis 1a: A subsidiary in a host country with weak IPR protection will likely build an ICN with high small-worldness.

IKNs are different, as they are based on knowledge-relatedness. Two randomly chosen knowledge elements in a small-world IKN are likely to be highly interrelated and connected through a small number of linkages (Schilling, 2005). Yayavaram and Ahuja (2008) suggested that such a structure in a knowledge base allows for a broad, deep, and efficient search. However, it also enables competitors to trawl a subsidiary's current knowledge network for combination or imitation opportunities. Thus, small-worldness in an IKN can exacerbate the risk of knowledge leaks. However, when a subsidiary's IKN is not tightly interconnected, access to a single part of it is of less value in 
isolation (Liebeskind, 1997). Leaking bits and pieces of knowledge elements to competitors is usually of little consequence for network elements (Kim, 2016), limiting the damage a competitor can cause.

Learning is generally associative (Cohen \& Levinthal, 1990). In a small-world IKN characterized by highly interrelated knowledge components, competitors need access to only a few knowledge components to obtain an in-depth understanding of a firm's core technologies. In an environment with weak IPR protection, the above situation is a serious risk. One defense would be to disperse key information that may be difficult to protect through the legal system. Dispersing and decentralizing information can raise imitators' search costs, making it difficult to understand and merge from different sources. The costs and difficulties reduce the chance of someone copying it successfully. In support of the above statement, an R\&D manager said in an interview that he prefers to hide the connections among elements of his firm's core knowledge to prevent imitators from "pulling out the radish and bringing out the mud." A fragmented IKN decreases the incentives for misappropriation. Others have access to only limited knowledge or information.

Hypothesis 1b: A subsidiary in a host country with weak IPR protection will likely build an IKN with low small-worldness.

Once an MNE's subsidiary has built its networks and learning paths in a host country, the MNE can accumulate resources and capabilities that may be useful for its subsidiary (Delios \& Beamish, 2001). In a country with inadequate IPR protection, an MNE's specific host-country experience may help its subsidiaries. Host-country experience builds local knowledge and connections that can sometimes prevent local competitors from exploiting any proprietary knowledge they manage to steal. In this situation, ties with the government and core stakeholders can be advantageous (Gassmann, Beckenbauer, \& Friesike, 2012; Yang et al., 2004). An MNE with host-country experience knows how to help a subsidiary monitor competitors, overcome the liability of foreignness, and apply suitable knowledge protection measures. The need for maintaining small-worldness will depend on what other defense mechanisms are available. Alternative measures can add extra barriers to knowledge spillovers. For instance, an experienced MNE can share learning with its subsidiaries on developing inter-organizational relationships with local partners in a host country (Du \& Williams, 2017).

Hypothesis 2: The relationship between weak IPR protection at a host location and the smallworldness of a subsidiary's ICN and IKN will be weakened when the parent firm has more hostcountry experience.

\section{METHODOLOGY}

\section{Data}

The empirical setting for this study was the pharmaceutical industry. We used the Compustat database to identify all 1,401 public pharmaceutical firms ${ }^{3}$ in the US during the period 1980-2017, and the Orbis database published by Bureau Van Djik (BVD) to obtain the names and locations of their foreign subsidiaries (Beukel \& Zhao, 2018). We identified 742 pharmaceutical firms together with their subsidiaries. Consistent with the approach of Zhao (2006) and Alcácer and Zhao (2012), we focused on the foreign subsidiaries that conducted R\&D during the analysis period. The final sample consisted of 401 foreign subsidiaries of 121 pharmaceutical firms and located in 39 countries. The final data panel contained 7781 subsidiary-year observations ${ }^{4}$.

The index of IPR protection came from the Ginarte and Park (GP) index (Ginarte \& Park, 1997) supplemented by the Fraser Institute's Property Protection Index, an index of economic freedom worldwide (Kunčič, 2014).

The information on subsidiaries' R\&D activities was from patent records retrieved from the European Patent Office's Patstat database. The firms in the sample all together applied for 223,074 patents from 1980 to 2017. Additional data on national characteristics were from the World Bank's database, and alliance information was from the SDC Platinum database.

A major complication was that a firm's identifiers in each database were different $t^{5}$. Thus, we manually matched firm names with their identifiers. We considered the firms with matching names and addresses to be the same firm. The search function of the BVD Orbis database was also helpful. Upon submitting a list of firms to the BVD system, a matching process produced a set of firms that best matched the specified search criteria. In this study, we used the highest quality indicator (a total score 
above 95\%), and confirmed the matched results manually by screening the available public information (e.g., LexisNexis and using Google).

\section{Variables}

The study had two dependent variables: a subsidiary's ICN and IKN small-worldness. On the basis of the patenting data, we constructed an ICN and IKN for each subsidiary each year. We used the application year to assign each patent to a firm because it closely indicates the timing of a technology's creation. We also employed co-author ties between all the inventors in a subsidiary to construct its annual ICNs. In an ICN, a "node" was an inventor and a "tie" was a patent co-authorship.

The annual IKNs were constructed using the cooccurrence of patents' full-digit international patent classification (IPC) codes (Belderbos et al., 2013). The IPC is a hierarchical technology classification system used by the World Intellectual Property Organization, which classifies patents on the basis of their key areas of technology (e.g., G01N33/531 and G01N33/566 in Appendix Figure 2). In an IKN, a "node" was an IPC code and a "tie" was indicated by two IPC codes classifying the same patent. In other words, if two IPC codes were co-present, a tie existed between those knowledge elements.

To quantify a network's small-world nature, we calculated a clustering coefficient and the whole network path length for each subsidiary each year. The small-worldness quotient calculation should use a random network of the same size as a baseline (Gulati et al., 2012; Uzzi \& Spiro, 2005). The next step was estimating the ratio of observed to random clustering and the ratio of observed to the random path length (Gulati et al., 2012). We used sizeadjusted ratios of clustering coefficients (CC ratios) and average path lengths (PL ratios) to eliminate the distorting effect of network size and the CC ratio/PL ratio to evaluate the small-world quotient. Appendix 2 presents the technical details.

We used an index of the IPR protection strength as the key independent variable. The GP index and Fraser IPR index have different scales. We normalized these indices by dividing them by their maximum values. We used the average of the two normalized indices as a measure of the IPR protection strength. The results remained robust after using each index individually.

Host-country experience was the key moderating variable. We based it on a parent firm's history in a host country and quantified it as the sum of the years all of the parent's subsidiaries had been operating in the host country (Henisz \& Delios, 2001; Li et al., 2015; Yang et al., 2015).

We also included several control variables. A subsidiary's R\&D productivity was quantified using the number of patents for which it applied. Knowledge breadth was the average number of technology classes per patent. We considered the average number of inventors per patent (termed knowledge workers) in the analyses as a control variable. We included the average number of citations per patent as an indicator of impact. We measured the geographic scope by the average number of country filings per patent. We also added the count of a subsidiary's alliance partners (termed alliance) along with the number of a subsidiary's sister firms in the host country (termed local sister).

The parent firm's productivity $p_{p}$ knowledge breadth $_{p}$, knowledge workers , impact $_{p}$, and geographic scope ${ }_{p}$ were considered in the models. They were quantified in the same way as the subsidiaries, with the $p$ subscripts distinguishing the two sets of variables. A parent firm's total assets were another control. R\&D per employee for the parent firm was also included.

Knowledge transfer from the subsidiary to its parent firm was represented by the backward citations in the parent's patents to those of the subsidiary. Technology similarity with the parent was the number of technology classifications common to a subsidiary's patents and its parent divided by the total number of technology classifications of their patents together. Collaboration with the parent was quantified using the number of their co-invention divided by the total number of the subsidiary's patents.

GDP per capita and the amount of foreign direct investment (FDI) in the host country were included in the model to describe the host country ${ }^{6}$.

\section{Modeling}

We evaluated seemingly unrelated regressions (SURs) to test the relationship between IPR protection and subsidiaries' internal network structures. The SUR approach simultaneously analyzes a set of models that are "seemingly" unrelated, but whose error terms are likely to be correlated. Independent analyses of such models may result in misleading statistical significance. The use of SURs addresses this issue by incorporating the contemporaneous correlation of error terms across models, and producing parameter estimates for all relevant models 
in a single iterative procedure, resulting in a more efficient parameter estimation than independent analyses (Zellner, 1962). SUR is appropriate when multiple dependent variables and identical independent variables exist across equations, and when both equations in each pair draw from the same dataset (Agarwal et al., 2004; Cannella \& McFadyen, 2016). It is widely used in network research when the dependent variables are network characteristics, such as the deletion and addition of nodes (Cannella \& McFadyen, 2016). SUR corrects the correlation between the models' error terms.

In this study, a firm's unobserved characteristics included in error terms, such as individual-organization fit or absorptive capacity, might simultaneously affect both of its intra-networks (Cho \& Lee, 2004; Kleinbaum, 2012). Consequently, the error terms of two models predicting the small-worldness of ICNs and IKNs would be correlated. Thus, we estimated the following regressions: for such endogeneity would result in biased coefficient estimates, potentially supporting faulty conclusions (Hamilton \& Nickerson, 2003).

To address this possibility, we should conduct an analysis that provides for exogenous shifts in the strength of IPR (Hamilton \& Nickerson, 2003). The analysis would allow the estimating of the relationship strength between the IPR situation and firm internal network configurations. The specific source of exogenous variation exploited here was the implementation of the WTO's TRIPS principles. The TRIPS system requires a country to satisfy minimum IPR protection standards. Thus, it was a plausibly exogenous variation (Delgado et al., 2013; Ivus, 2010) because its enactment did not reflect any subsidiary's strategic behavior (Campi et al., 2019). TRIPS implementation ${ }^{7}$ served as a quasinatural experiment, wherein we assigned observations to pre- and post-groups and treatment and control groups. A difference-in-differences

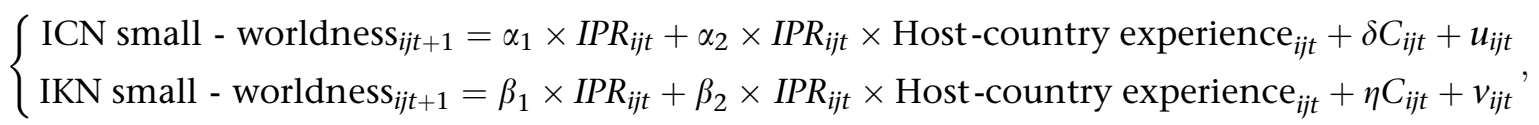

where $i$ indices firms, $j$ indices countries, $t$ indices years, and $u_{i j t}$ and $v_{i j t}$ are the error terms. $C_{i j t}$ is a matrix of control variables, including subsidiary, parent firm, dyadic, and country-level variables. The coefficients of interest are $\alpha_{1}$ and $\beta_{1}$, which measure the change in the value of ICN and IKN small-worldness corresponding to a one-point increase in the IPR index. $\alpha_{2}$ and $\beta_{2}$ test H2.

Some unobservable firm characteristics might create a spurious relationship between the IPR index and the internal networks' structures. For example, a firm pursuing cost-reducing $R \& D$ is likely to choose a country with cheap labor costs but weak IPR protection (Zhao, 2006). Its costcutting would also affect the configurations of its networks of $R \& D$ personnel and technological knowledge (Hoskisson et al., 1993; Zhou \& Wu, 2010). In such cases, an endogeneity problem could arise if an unobserved or omitted variable (costreducing $R \& D$ in this example) is confounding the independent (i.e., IPR protection) and dependent variables (i.e., small-worldness). Failure to correct approach (Card \& Krueger, 2000) was applied to estimate changes in the countries' IPR indices. In the 2nd stage, we used the predicted IPR index from the 1st stage to determine a subsidiary's future defensive tactics.

In the 1 st stage, we predicted $\mathrm{IPR}_{i j t}$ using

$$
\begin{aligned}
\mathrm{IPR}_{i j t}= & \gamma_{0}+\gamma_{1} * \text { Post }_{i j t} * \text { Treatment }_{i j t}+\gamma_{2} * C_{i j t} \\
& +w_{i j t},
\end{aligned}
$$

where Treatment ${ }_{i j t}$ takes a value of 1 for subsidiaries whose host country had implemented the TRIPS protocols and 0 for the others. Post $t_{i j t}$ is 1 for observations after a country had implemented the TRIPS protocols and 0 beforehand. The coefficient of interest in this stage is $\gamma_{1}$. In the 2nd stage, the main models were the same as (1), except that we replaced the IPR index with the predicted value.

\section{RESULTS}

Table 2 reports summary statistics and simple correlations relating to all variables. The variables' largest variance inflation factor was 4.40 , so multicollinearity was not a serious concern. 


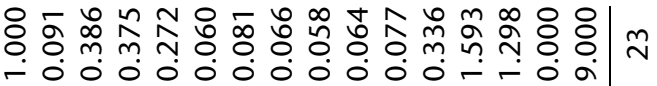

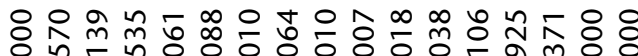

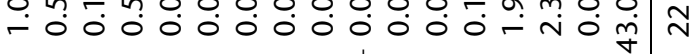

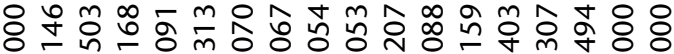

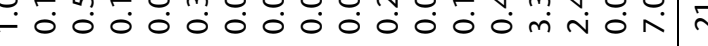

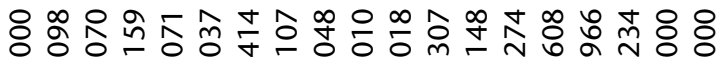

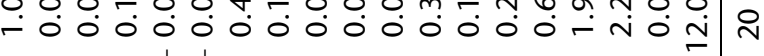

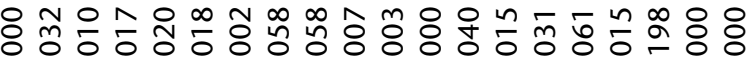

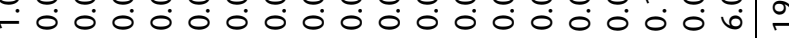

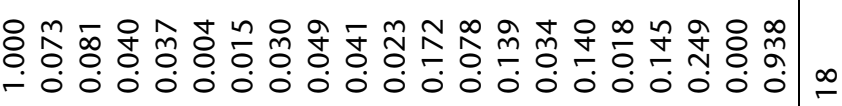
\& f -

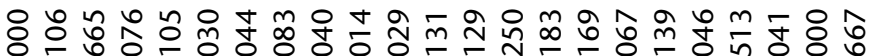

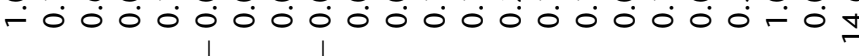

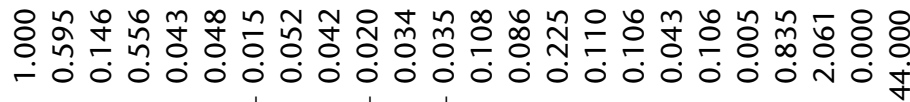

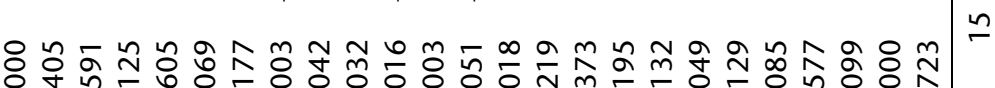

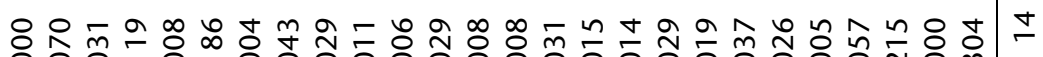
-

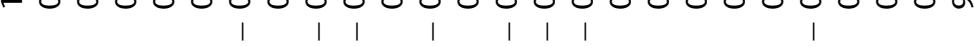

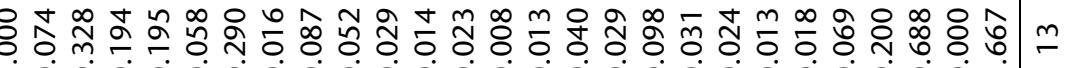

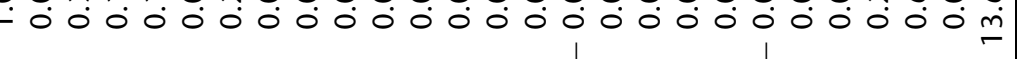
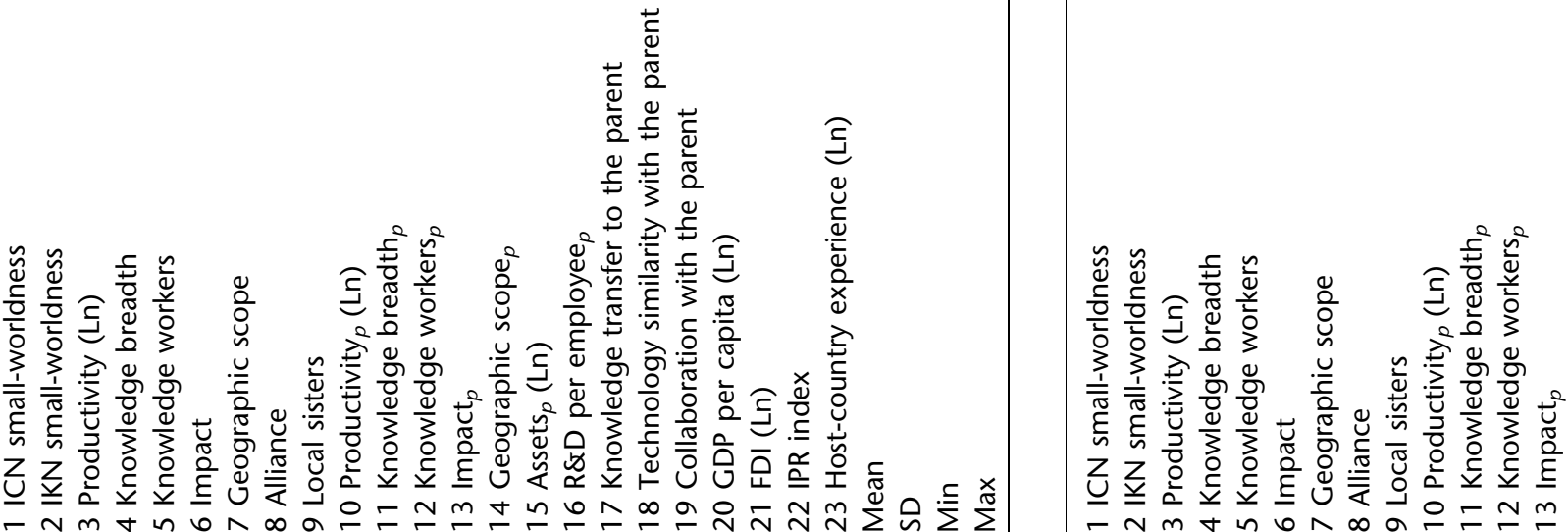


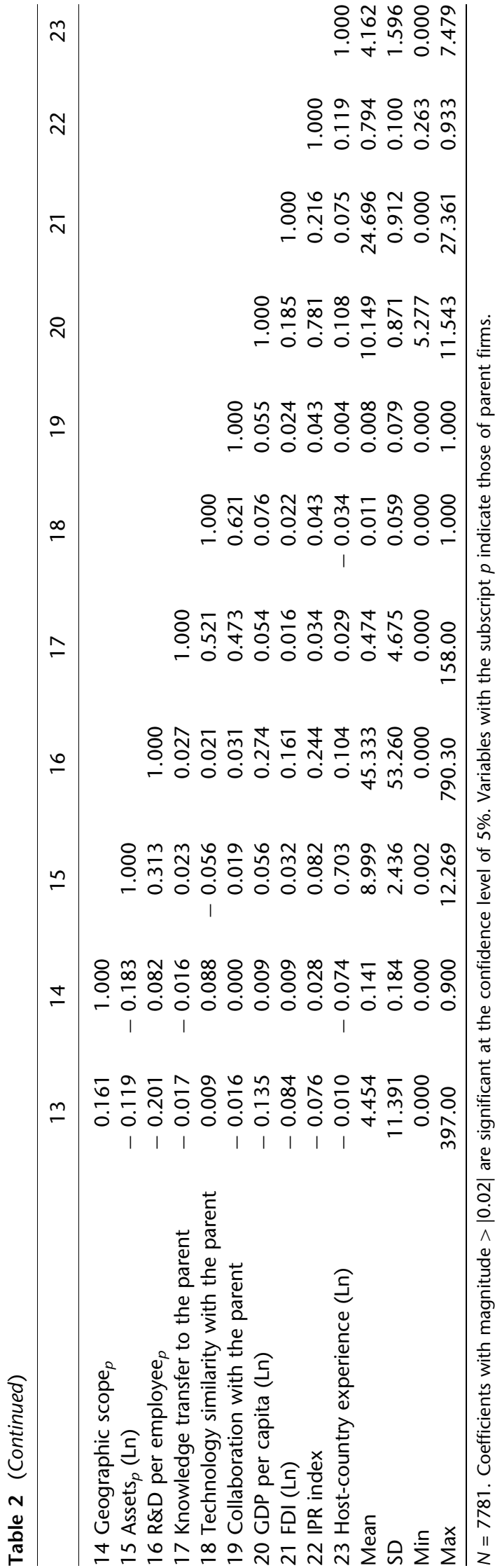

Table 3 displays the coefficients of the 2SLS models. Model 1 predicted IPR in the first stage. The corresponding Cragg-Donald $F$ statistic was 1720.2, well above the threshold for "strong" instruments (Staiger \& Stock, 1997). The $p$ value of the Anderson Canon correlation LM statistic was $\leq 0.001$. The coefficient of the Treatment $\times$ Post term was significant and positive in Model 1.

The predicted IPR index coefficient was significant and negative in Model $2(\beta=-0.044$; $p \leq 0.05)$, suggesting an association between strong IPR and a low ICN small-worldness. This finding indicates that a subsidiary responds to weak IPR protection by building an ICN characterized by a high small-worldness, supporting Hypothesis 1a. The predicted IPR index was a significant and positive predictor in Model 4 $(\beta=0.022 ; p \leq 0.001)$, suggesting an association between strong IPR protection and a high IKN small-worldness. This finding implies that a subsidiary responds to weak IPR protection by building an IKN characterized by low small-worldness, supporting Hypothesis 1b.

Models 3 and 5 considered the possible moderating effect of host-country experience. The term coefficient representing an interaction between IPR protection and host-country experience was positive and statistically significant $(\beta=0.015 ; p \leq 0.05$ in Model 3). The corresponding interaction term coefficient in Model 5 was also significant $(\beta=-0.005 ; p \leq 0.01)$, supporting Hypothesis 2 .

Figure 1 displays the relationships between IPR protection and internal network small-worldness for different levels of host-country experience when all the other variables were constrained at their mean values. The high-level subgroup was the upper quartile, and the low-level subgroup was the lower quartile, supporting Hypothesis 2.

The Treatment $\times$ Post coefficient in Model 1 in Table 3 suggests that IPR protection was better on average after a country implemented the TRIPS protocols. The average value of the IPR index was 0.79 . Thus, the strength of IPR protection increased by approximately $7.43 \%$ after the TRIPS agreement implementation, a relatively substantial strengthening. We conducted a placebo test in which half the treated years and half the treated countries were randomized. Then, we re-estimated the regressions with 500 sets of such placebos, and the "effect" (the average coefficient of Treatment $\times$ Post $)$ was not significant $(\beta=0.004$; $t=1.413 ; p>0.1)$. These results further proved 
Table 3 Coefficients of SURs predicting ICN and IKN small-worldness

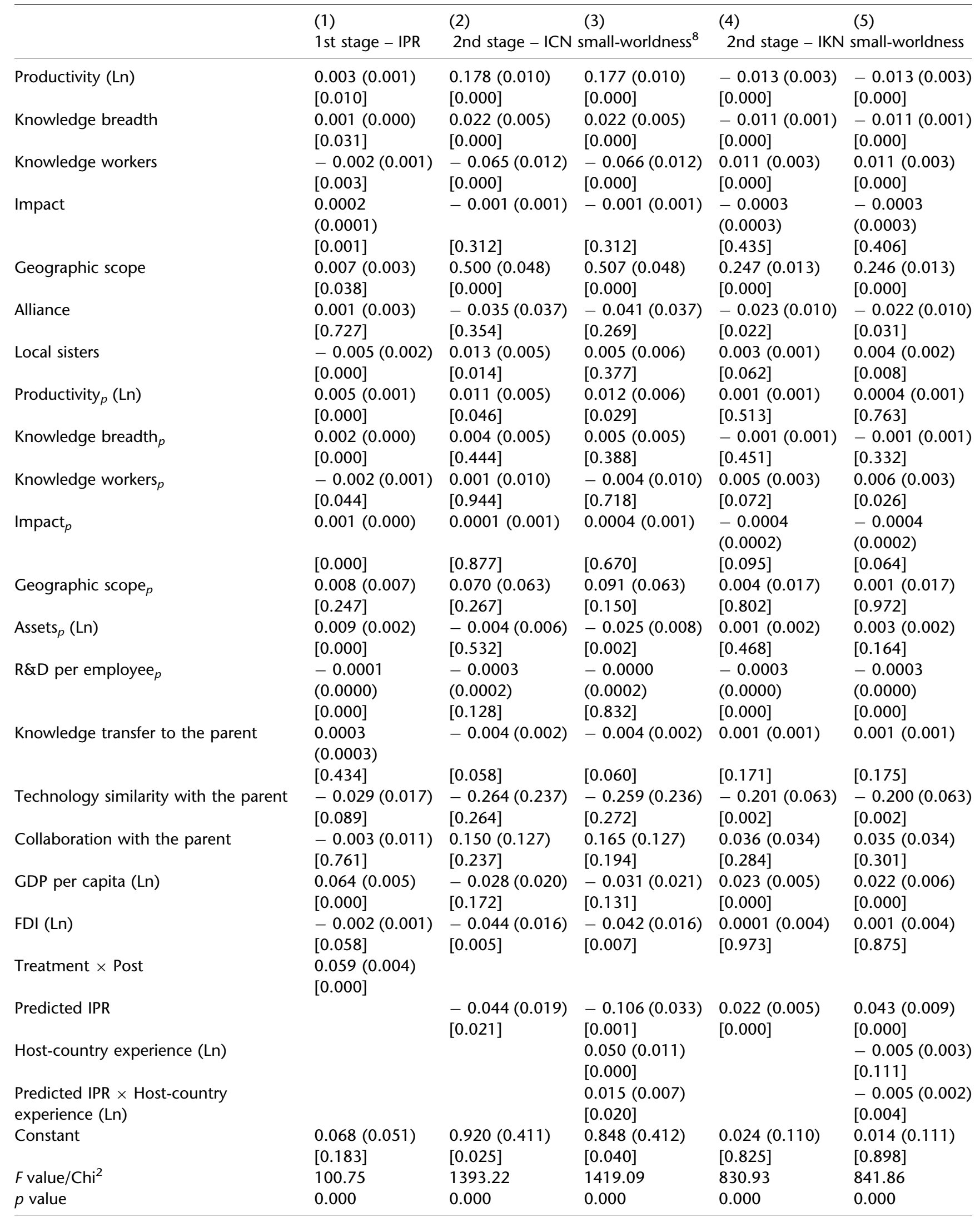




\begin{tabular}{|c|c|c|c|c|c|}
\hline & (1) & $(2)$ & (3) & (4) & (5) \\
\hline & 1st stage - IPR & 2nd st & small-worldness $^{8}$ & 2nd & small-worldness \\
\hline$R^{2}$ & 0.624 & 0.152 & 0.154 & 0.097 & 0.098 \\
\hline
\end{tabular}

Standard errors are shown in parentheses and $p$ values in brackets. Robust standard errors are clustered by a subsidiary in the first stage regression. Country fixed effects included. $n=7781$.

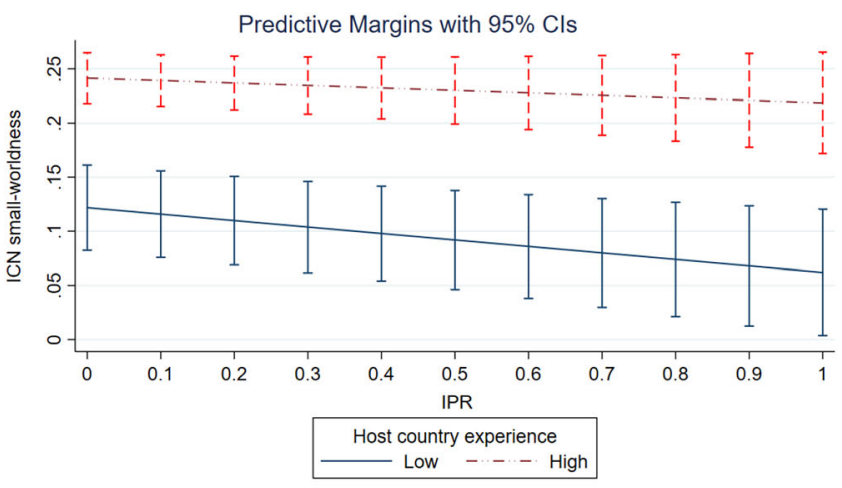

(a)

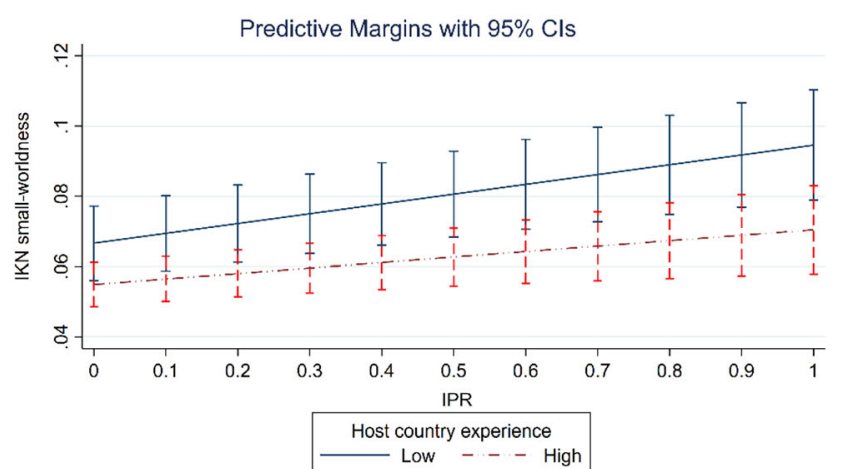

(b)

Figure 1 Moderating role of host-country experience.

the validity of the identification technique used in this study.

One check on the robustness of the results involved only host countries with more than five patents filed and had more than two million residents, of whom more than $1 \%$ had tertiary education in the focal year (Zhao, 2006). Another check omitted large firms that might be able to affect legislative outcomes. We also re-estimated the models, excluding subsidiaries whose patent productivities were among the top $10 \%$ of the sample. Another analysis excepted patents co-invented by a subsidiary with inventors from other firms. In that case, the focal subsidiary might have less control over the configuration of the ICN involved. Patents co-invented by the subsidiary and firms outside the MNE were excluded. Likewise, all patents co-invented with the parent or its other subsidiaries were disregarded. The pattern of the results remained consistent with the original findings in all these tests.

We also re-calculated the clustering using the geometric mean, maxima, and minima. Those results were almost identical to those of the original analysis. Some studies emphasize the significance of random models in modeling heterogeneity (Bell \& Jones, 2015). Therefore, we also tested random effects but found no significantly different results. Details of these tests are available from the authors on request.

\section{DISCUSSION AND CONCLUSIONS}

The results confirm that internal collaboration and knowledge networks can be adjusted to cope with situations in which a subsidiary's intellectual property is at risk. This study has been one of the first to provide empirical evidence regarding this assumption. The findings also show that such measures are vital when the MNE has less experience in the host country.

This study contributes to the literature in three ways. The findings enhance scholarly understanding of the role of internal linkages in knowledge appropriability in foreign subsidiaries. They support some arguments of internalization studies to the effect that tight internal organization can protect innovations from imitation by local competitors (Sanna-Randaccio \& Veugelers, 2007; Zhao, 2006). Thus, this study further advances this line of reasoning by recognizing the prominence that the network perspective deserves in analyzing the roles of internal tools (Alcácer \& Zhao, 2012) and moving scholarly attention from dyads and portfolios to networks. Prior research on foreign subsidiaries considered their knowledge workers and 
knowledge elements but often disregarded the context of a broad internal network of knowledge workers or elements. The network structure matters because it indicates that even subsidiaries with similar numbers or types of inventors or similar knowledge portfolios may still have different abilities to govern their knowledge activities effectively because of structural variations (Yayavaram \& Ahuja, 2008). Neglecting the network perspective masks information significant for subsidiary management decisions. Viewing a subsidiary as a network of relationships makes the network approach suitable for investigating and tracking its knowledge-creating activities.

This work has delineated two different internal networks in foreign subsidiaries and differentiated their underlying mechanisms in protecting IPR. Considerable theoretical evidence shows that social complexity increases the difficulty and cost of appropriating firm knowledge (Nelson \& Winter, 1982). Our small-world approach advances this line of inquiry by explaining that a small-world ICN structure can increase the causal ambiguity and decrease the valuable knowledge imitability. On this basis, an outsider will have difficulty determining who contributes what, how they interact, and how much each contributes, increasing the costs of misappropriating firm knowledge.

Our findings tend to support the view that a firm can rely on knowledge-related measures to make it hard for a competitor to interpret and imitate its technology (Xie \& Li, 2015, 2018). Breadth and diversity (Perri et al., 2015), process fragmentation (Gooris \& Peeters, 2016), and international patenting are all deemed helpful. Yet, prior research treated the firm knowledge base as an aggregation of independent knowledge elements and ignored the elements' interaction. This gap raises a vital question: how does a firm modify its knowledge network to inhibit knowledge spillover? Our findings offer some explanation.

Our findings advance prior work, such as Baldwin and Henkel's (2015) "isolating mechanisms" and Gooris and Peeters' (2016) "fragmentation mechanism." These scholars showed that dispersing tasks or components across different research units (organizationally or geographically) helps protect firm innovation, given that the knowledge value in any unit is relatively limited. Our study complements the above findings by using IKN small-worldness to indicate internal knowledge relatedness and explain how limiting the small-worldness of a firm's knowledge network serves as a "knowledge unrelatedness mechanism," dividing its knowledge base into discrete sub-clusters. Internal network defenses reside internally and are more universally applicable.

By differentiating the underlying mechanisms that make internal collaboration and knowledge networks effective, some conceptual arguments proposed in this study are consistent with related work, suggesting that the underlying mechanism of the search process in a knowledge network is distinct from that in a collaboration network (Wang et al., 2014). Wang et al. (2014) suggested that the egocentric structural features in a collaboration network are about search opportunities and constraints stemming from human interactions. The egocentric structural features in a knowledge network provide cognitive convenience in searching for a knowledge element through related elements. Our study has built upon but departed from their research by emphasizing the roles of collaboration and knowledge networks in protecting innovation in situations where IPR protection is weak. The findings indicate different protection mechanisms on the basis of the small-world organization of ICNs and IKNs.

Finally, international business scholars have examined the drivers of network dynamics. Network position (Shi et al., 2014) and national levels of trust (Kwon et al., 2016) have gathered considerable attention. Unlike prior research that primarily dealt with external networks with foreign partners or other subsidiaries, we focus on internal networks. Relying on theoretical insights into multilevel emergence (Kozlowski et al., 2013), and building on findings that describe specifically how national differences affect firm strategy (Kwon et al., 2016), we link local IPR protection with firm network structures. Consequently, we extend this line of inquiry by using a multilevel view to link institutional factors with foreign subsidiaries' internal network dynamics.

\section{Managerial Implications}

Our findings have significant implications for foreign subsidiary innovation in countries with weak IP regimes. Most foreign subsidiaries face significant challenges of knowledge leakage risks in such an environment. Thus, this study provides strategies for foreign subsidiaries to mitigate such concerns. A foreign subsidiary in an environment with weak IP protection can consider rearranging its ICNs to increase their small-worldness. This process involves strengthening cooperation between its research units and fostering bridge-building, which 
may require interdepartmental conferences or seminars to build inter-departmental coordination and improve information sharing. Subsidiaries can also consider reshaping their coupling structures for technical knowledge. A subsidiary may be cunning and even deploy some confusing or deceptive technologies to deceive imitators. It can decentralize its knowledge network by forming a chain structure or separating knowledge bases to increase competitors' search costs and time. We find that foreign subsidiary managers exposed to knowledge leakage risks may find it worthwhile to improve their subsidiary's internal network designs.

\section{Limitations and Future Work}

Firms have other significant internal networks beyond those treated here. The effects of other networks (e.g., citation networks) on knowledge protection may merit scholarly attention. Moreover, reshaping internal networks has some costs. Increasing ICN small-worldness may involve coordination costs, whereas decreasing IKN smallworldness may raise search costs. Investigating the cost-benefit trade-offs may be worthwhile.

In this study, we have worked exclusively with foreign subsidiaries of large pharmaceutical firms. These firms inevitably confront more knowledge leakage risks than other types of firms. Caution is called for in generalizing these findings to other industries. Whether they hold for foreign subsidiaries of privately-held and/or smaller firms is also unclear. Foreign subsidiaries of smaller firms may be more interested in benefiting from knowledge spill-in rather than spill-over risks. Therefore, future research should collect primary data and investigate the possible differences in internal network responses between diverse foreign subsidiaries.

\section{ACKNOWLEDGEMENTS}

We are grateful to Pervez Ghauri, Alain Verbeke, and three anonymous reviewers for their valuable suggestions. The research is supported in part by the Research Grants Council of Hong Kong (HKUST\#16505817 and 16507219), National Natural Science Foundation of China (Grants 71932007 and 71904191), Fund for building world-class universities (disciplines) of Renmin University of China (No.
KYGJC2020012), and University of Chinese Academy of Sciences (No. Y95402JXX2).

\section{NOTES}

${ }^{1}$ We reviewed the most recent research using the following criteria: (1) Articles published since 2015 and (2) IB journals ranked 3rd or higher in the 2018 Association of Business Schools' Academic Journal Quality Guide. The search used the following keywords: "IPR," "MNE," "subsidiary," "knowledge protection," "knowledge leakage," "knowledge spill-over," and "network." Table 1 presents the ten most recent related studies.

${ }^{2}$ https://www.investopedia.com/ask/answers/ 060115/how-much-drug-companys-spendingallocated-research-and-development-average.asp.

${ }^{3}$ SIC codes were $2833,2834,2835$, and 2836.

${ }^{4}$ The sample ended in 2016 to allow applying a one-year lag to the dependent variables. A total of 7,781 observations were used in the regressions after excluding observations with missing values.

${ }^{5}$ For example, the unique identifier was Gvkey in Compustat and BVD ID in Orbis.

${ }^{6}$ We evaluated all of the control variables in year $t$. Natural logarithms of the Productivity, Productivity $_{p}$, Assets ${ }_{p}$, GDP per capita, FDI, and Hostcountry experience values were used. The unit of Assets $_{p}$ was million USD, the unit of R\&D expenditure per employee was million dollars per thousand persons, the unit of GDP per capita was dollars, and the unit of FDI was billion dollars.

${ }^{7}$ We manually read the law and regulation notifications for WTO members under Article 63.2 of the TRIPS to obtain the year each country implemented TRIPS principles. A total of 36 countries in the sample claimed to have adopted the TRIPS practices from 1980 to 2016.

${ }^{8}$ Following Maslach's and Sine's approach, we performed a modified Gram-Schmidt procedure (using the "orthog" command in Stata) to orthogonalize the predicted IPR values with GDP per capita in the second stage regressions because of their high correlation (0.895) (Maslach, 2016; Sine et al., 2005). 


\section{REFERENCES}

Agarwal, R., Echambadi, R., Franco, A. M., \& Sarkar, M. B. 2004. Knowledge transfer through inheritance: Spin-out generation, development, and survival. Academy of Management Journal, 47(4): 501-522.

Agarwal, R., Ganco, M., \& Ziedonis, R. H. 2009. Reputations for toughness in patent enforcement: Implications for knowledge spillovers via inventor mobility. Strategic Management Journal, 30(13): 1349-1374.

Ahuja, G. 2000. Collaboration networks, structural holes, and innovation: A longitudinal study. Administrative Science Quarterly, 45(3): 425-455.

Alcácer, J., \& Zhao, M. 2012. Local R\&D strategies and multilocation firms: The role of internal linkages. Management Science, 58(4): 734-753.

Alnuaimi, T., \& George, G. 2016. Appropriability and the retrieval of knowledge after spillovers. Strategic Management Journal, 37(7): 1263-1279.

Amaral, L. A. N., Scala, A., Barthélémy, M., \& Stanley, H. E. 2000. Classes of small-world networks. Proceedings of the National Academy of Sciences U.S.A., 97(21): 11149-11152.

Athreye, S., Batsakis, G., \& Singh, S. 2016. Local, global, and internal knowledge sourcing: The trilemma of foreign-based R\&D subsidiaries. Journal of Business Research, 69(12): 5694-5702.

Balachandran, S., \& Hernandez, E. 2016. Liberty in law? Intellectual property rights and global alliance networks. Academy of Management Proceedings. https://doi.org/10. 5465/ambpp.2016.186.

Baldwin, C. Y., \& Henkel, J. 2015. Modularity and intellectual property protection. Strategic Management Journal, 36(11): 1637-1655.

Belderbos, R., Leten, B., \& Suzuki, S. 2013. How global is R\&D? Firm-level determinants of home-country bias in R\&D. Journal of International Business Studies, 44(8): 765-786.

Bell, A., \& Jones, K. 2015. Explaining fixed effects: Random effects modeling of time-series cross-sectional and panel data. Political Science Research, 3(1): 133-153.

Berry, H. 2017. Managing valuable knowledge in weak IP protection countries. Journal of International Business Studies, 48(7): 787-807.

Berry, H. 2020. Internationalizing firm innovations: The influence of multimarket overlap in knowledge activities. Journal of International Business Studies, 51: 963-985. https://doi.org/ 10.1057/s41267-019-00284-y.

Beukel, K., \& Zhao, M. 2018. IP litigation is local, but those who litigate are global. Journal of International Business Policy, 1(1-2): 53-70.

Borgatti, S. P., \& Halgin, D. S. 2011. On network theory. Organization Science, 22(5): 1168-1181.

Bosworth, D., \& Yang, D. 2000. Intellectual property law, technology flow and licensing opportunities in the People's Republic of China. International Business Review, 9(4): 453-477.

Buckley, P. J., \& Casson, M. C. 2009. The internalisation theory of the multinational enterprise: A review of the progress of a research agenda after 30 years. Journal of International Business Studies, 40(9): 1563-1580.

Campi, M., Dueñas, M., Barigozzi, M., \& Fagiolo, G. 2019. Intellectual property rights, imitation, and development: The effect on cross-border mergers and acquisitions. The Journal of International Trade \& Economic Development, 28(2): 230-256.

Cannella, A. A., \& McFadyen, M. A. 2016. Changing the exchange: The dynamics of knowledge worker ego networks. Journal of Management, 42(4): 1005-1029.

Card, D., \& Krueger, A. B. 2000. Minimum wages and employment: A case study of the fast-food industry in New Jersey and Pennsylvania, reply. American Economic Review, 90(5): 1397-1420.
Chen, L., Li, Y., \& Fan, D. 2018. How do emerging multinationals configure political connections across institutional contexts? Global Strategy Journal, 8(3): 447-470.

Cho, K. R., \& Lee, J. 2004. Firm characteristics and MNC's intranetwork knowledge sharing. Management International Review, 44(4): 435-455.

Choi, J., \& Contractor, F. J. 2016. Choosing an appropriate alliance governance mode: The role of institutional, cultural and geographical distance in international research \& development (R\&D) collaborations. Journal of International Business Studies, 47(2): 210-232.

Clark, K., \& Lengnick-Hall, M. L. 2012. MNC practice transfer: Institutional theory, strategic opportunities and subsidiary HR configuration. The International Journal of Human Resource Management, 23(18): 3813-3837.

Cohen, W. M., \& Levinthal, D. A. 1990. Absorptive capacity: A new perspective on learning and innovation. Administrative Science Quarterly, 35(1): 128-152.

Colbert, B. A. 2004. The complex resource-based view: Implications for theory and practice in strategic human resource management. Academy of Management Review, 29(3): 341-358.

Coviello, N. E. 2006. The network dynamics of international new ventures. Journal of International Business Studies, 37(5): 713-731.

Dang, Q. T., Jasovska, P., \& Rammal, H. G. 2020. International business-government relations: The risk management strategies of MNEs in emerging economies. Journal of World Business, 55(1): 101042.

Davis, G. F., Yoo, M., \& Baker, W. E. 2003. The small world of the American corporate elite, 1982-2001. Strategic Organization, 1(3): 301-326.

De Carolis, D. M. 2003. Competencies and imitability in the pharmaceutical industry: An analysis of their relationship with firm performance. Journal of Management, 29(1): 27-50.

Delgado, M., Kyle, M., \& McGahan, A. M. 2013. Intellectual property protection and the geography of trade. The Journal of Industrial Economics, 61(3): 733-762.

Delios, A., \& Beamish, P. W. 2001. Survival and profitability: The roles of experience and intangible assets in foreign subsidiary performance. Academy of Management Journal, 44(5): 1028-1038.

Du, J., \& Williams, C. 2017. Innovative projects between MNE subsidiaries and local partners in China: Exploring locations and inter-organizational trust. Journal of International Management, 23(1): 16-31.

Ellis, P. D. 2011. Social ties and international entrepreneurship: Opportunities and constraints affecting firm internationalization. Journal of International Business Studies, 42(1): 99-127.

Faccio, M. 2006. Politically connected firms. American Economic Review, 96(1): 369-386.

Feinberg, S. E., \& Gupta, A. K. 2009. MNC subsidiaries and country risk: Internalization as a safeguard against weak external institutions. Academy of Management Journal, 52(2): 381-399.

Flammer, C., \& Kacperczyk, A. 2019. Corporate social responsibility as a defense against knowledge spillovers: Evidence from the inevitable disclosure doctrine. Strategic Management Journal, 40(8): 1243-1267.

Gassmann, O., Beckenbauer, A., \& Friesike, S. 2012. Profiting from innovation in China. Berlin: Springer.

Ginarte, J. C., \& Park, W. G. 1997. Determinants of patent rights: A cross-national study. Research Policy, 26(3): 283-301.

Gooris, J., \& Peeters, C. 2016. Fragmenting global business processes: A protection for proprietary information. Journal of International Business Studies, 47(5): 535-562.

Gulati, R., Sytch, M., \& Tatarynowicz, A. 2012. The rise and fall of small worlds: Exploring the dynamics of social structure. Organization Science, 23(2): 449-471. 
Hamilton, B. H., \& Nickerson, J. A. 2003. Correcting for endogeneity in strategic management research. Strategic Organization, 1(1): 51-78.

Henisz, W. J., \& Delios, A. 2001. Uncertainty, imitation, and plant location: Japanese multinational corporations, 1990-1996. Administrative Science Quarterly, 46(3): 443-475.

Hernandez, E., \& Menon, A. 2019. Corporate strategy and network change. Academy of Management Review.. https:// doi.org/10.5465/amr.2018.0013.

Hoskisson, R. E., Hitt, M. A., \& Hill, C. W. L. 1993. Managerial incentives and investment in $R \& D$ in large multiproduct firms. Organization Science, 4(2): 325-341.

Inkpen, A., Minbaeva, D., \& Tsang, E. W. K. 2019. Unintentional, unavoidable, and beneficial knowledge leakage from the multinational enterprise. Journal of International Business Studies, 50(2): 250-260.

lurkov, V., \& Benito, G. 2018. Domestic alliance networks and regional strategies of MNEs: A structural embeddedness perspective. Journal of International Business Studies, 49(8): 1033-1059.

Ivus, O. 2010. Do stronger patent rights raise high-tech exports to the developing world? Journal of International Economics, 81(1): 38-47.

Ivus, O., Park, W. G., \& Saggi, K. 2017. Patent protection and the composition of multinational activity: Evidence from US multinational firms. Journal of International Business Studies, 48(7): 808-836.

Joel, A. C. B., \& Oliver, C. 1991. Institutional linkages and organizational mortality. Administrative Science Quarterly, 36(2): 187-218.

Kim, M. 2016. Geographic scope, isolating mechanisms, and value appropriation. Strategic Management Journal, 37(4): 695-713.

Kleinbaum, A. M. 2012. Organizational misfits and the origins of brokerage in intrafirm networks. Administrative Science Quarterly, 57(3): 407-452.

Kleinbaum, A. M., \& Stuart, T. E. 2014. Network responsiveness: The social structural microfoundations of dynamic capabilities. Academy of Management Perspectives, 28(4): 353-367.

Kogut, B., \& Walker, G. 2001. The small world of Germany and the durability of national networks. American Sociological Review, 66(3): 317-335.

Kozlowski, S. W. J., Chao, G. T., Grand, J. A., Braun, M. T., \& Kuljanin, G. 2013. Advancing multilevel research design: Capturing the dynamics of emergence. Organizational Research Methods, 16(4): 581-615.

Kunčič, A. 2014. Institutional quality dataset. Journal of Institutional Economics, 10(1): 135-161.

Kurt, Y., \& Kurt, M. 2020. Social network analysis in international business research: An assessment of the current state of play and future research directions. International Business Review, 29(2): 101633.

Kwon, S., Haleblian, J., \& Hagedoorn, J. 2016. In country we trust? National trust and the governance of international R\&D alliances. Journal of International Business Studies, 47(7): 807-829.

Li, J., Qian, C., \& Yao, K. 2015. Confidence in learning: interand intra-organizational learning in foreign market entry location decisions. Strategic Management Journal, 36(6): 918-929.

Li, J., \& Xie, Z. 2011. Global R\&D strategies in an emerging economy: The development and protection of technological competencies. European Management Review, 8(3): 153-164.

Li, J., \& Xie, Z. 2016. Governance structure and the creation and protection of technological competencies: International R\&D joint ventures in China. Management International Review, 56(1): 123-148.

Liebeskind, J. P. 1997. Keeping organizational secrets: Protective institutional mechanisms and their costs. Industrial and Corporate Change, 6(3): 623-663.
Liu, M., \& La Croix, S. 2015. A cross-country index of intellectual property rights in pharmaceutical inventions. Research Policy, 44(1): 206-216.

Marin, A., \& Wellman, B. 2011. Social network analysis: An introduction. In J. Scott, \& P. J. Carrington (Eds.), The SAGE handbook of social network analysis. London: Sage.

Maslach, D. 2016. Change and persistence with failed technological innovation. Strategic Management Journal, 37(4): 714-723.

Meyer, K. E., \& Peng, M. W. 2016. Theoretical foundations of emerging economy business research. Journal of International Business Studies, 47(1): 3-22.

Milgram, S. 1967. The small world problem. Psychology Today, 2(1): 60-67.

Nandkumar, A., \& Srikanth, K. 2016. Right person in the right place: How the host country IPR influences the distribution of inventors in offshore $R \& D$ projects of multinational enterprises. Strategic Management Journal, 37(8): 1715-1733.

Nelson, R. R., \& Winter, S. G. 1982. The Schumpeterian tradeoff revisited. The American Economic Review, 72(1): 114-132.

Newman, M. E. J. 2001. The structure of scientific collaboration networks. Proceedings of the National Academy of Sciences U.S.A., 98(2): 404-409.

Newman, M. E. J., Watts, D. J., \& Strogatz, S. H. 2002. Random graph models of social networks. Proceedings of the National Academy of Sciences U.S.A., 99(suppl 1): 2566-2572.

Ostergard, R. L. 2000. The measurement of intellectual property rights protection. Journal of International Business Studies, 31(2): 349-360.

Perri, A., Oriani, R., \& Rullani, F. 2015. MNC strategies to limit spillovers: How subsidiaries manage knowledge breadth to decrease spillovers. Academy of Management Proceedings. https://doi.org/10.5465/ambpp.2015.14688abstract.

Phelps, C., Heidl, R., \& Wadhwa, A. 2012. Knowledge, networks, and knowledge networks: A review and research agenda. Journal of Management, 38(4): 1115-1166.

Pisani, N., \& Ricart, J. E. 2018. Offshoring innovation to emerging countries: The effects of IP protection and cultural differences on firms' decision to augment versus exploit home-base-knowledge. Management International Review, 58(6): 871-909.

Qian, Y. 2007. Do national patent laws stimulate domestic innovation in a global patenting environment? A crosscountry analysis of pharmaceutical patent protection, 1978-2002. The Review of Economics and Statistics, 89(3): 436-453.

Rugman, A. M., \& Verbeke, A. 2003. Extending the theory of the multinational enterprise: Internalization and strategic management perspectives. Journal of International Business Studies, 34(2): 125-137.

Ryu, W., McCann, B. T., \& Reuer, J. J. 2018. Geographic colocation of partners and rivals: Implications for the design of R\&D alliances. Academy of Management Journal, 61(3): 945-965.

Sanna-Randaccio, F., \& Veugelers, R. 2007. Multinational knowledge spillovers with decentralised R\&D: A game-theoretic approach. Journal of International Business Studies, 38(1): $47-63$.

Schilling, M. A. 2005. A "small-world" network model of cognitive insight. Creativity Research Journal, 17(2-3): 131-154.

Schilling, M. A., \& Phelps, C. C. 2007. Interfirm collaboration networks: The impact of large-scale network structure on firm innovation. Management Science, 53(7): 1113-1126.

Shi, W. S., Sun, S. L., Pinkham, B. C., \& Peng, M. W. 2014. Domestic alliance network to attract foreign partners: Evidence from international joint ventures in China. Journal of International Business Studies, 45(3): 338-362.

Siegel, J. 2007. Contingent political capital and international alliances: Evidence from South Korea. Administrative Science Quarterly, 52(4): 621-666. 
Sine, W. D., Haveman, H. A., \& Tolbert, P. S. 2005. Risky business? Entrepreneurship in the new independent-power sector. Administrative Science Quarterly, 50(2): 200-232.

Song, J., \& Shin, J. 2008. The paradox of technological capabilities: A study of knowledge sourcing from host countries of overseas R\&D operations. Journal of International Business Studies, 39(2): 291-303.

Staiger, D., \& Stock, J. 1997. Instrumental variables regression with weak instruments. Econometrica, 65(3): 557-586.

Sun, J., Debo, L. G., Kekre, S., \& Xie, J. 2010. Component-based technology transfer in the presence of potential imitators. Management Science, 56(3): 536-552.

Tsai, W. 2001. Knowledge transfer in intraorganizational networks: Effects of network position and absorptive capacity on business unit innovation and performance. Academy of Management Journal, 44(5): 996-1004.

Uzzi, B., \& Spiro, J. 2005. Collaboration and creativity: The small world problem. American Journal of Sociology, 111(2): 447-504.

Wang, C., Rodan, S., Fruin, M., \& Xu, X. 2014. Knowledge networks, collaboration networks, and exploratory innovation. Academy of Management Journal, 57(2): 484-514.

Watts, D. J., \& Strogatz, S. H. 1998. Collective dynamics of 'small-world' networks. Nature, 393(6684): 440-442.

Xie, Z., \& Li, J. 2015. Demand heterogeneity, learning diversity and innovation in an emerging economy. Journal of International Management, 21(4): 277-292.

Xie, Z., \& Li, J. 2018. Exporting and innovating among emerging market firms: The moderating role of institutional development. Journal of International Business Studies, 49(2): 222-245.

Yamin, M., \& Kurt, Y. 2018. Revisiting the Uppsala internationalization model. International Marketing Review, 35(1): 2-17.

Yamin, M., \& Otto, J. 2004. Patterns of knowledge flows and MNE innovative performance. Journal of International Management, 10(2): 239-258.

Yang, D., Sonmez, M., \& Bosworth, D. 2004. Intellectual property abuses: How should multinationals respond? Long Range Planning, 37(5): 459-475.

Yang, J., Li, J., \& Delios, A. 2015. Will a second mouse get the cheese: Learning from early entrants' failures in a foreign market. Organization Science, 26(3): 908-922.
Yayavaram, S., \& Ahuja, G. 2008. Decomposability in knowledge structures and its impact on the usefulness of inventions and knowledge-base malleability. Administrative Science Quarterly, 53(2): 333-362.

Zellner, A. 1962. An efficient method of estimating seemingly unrelated regressions and tests for aggregation bias. Journal of the American Statistical Association, 57(298): 348-368.

Zhao, M. 2006. Conducting R\&D in countries with weak intellectual property rights protection. Management Science, 52(8): 1185-1199.

Zhelyazkov, P. I. 2018. Interactions and interests: Collaboration outcomes, competitive concerns, and the limits to triadic closure. Administrative Science Quarterly, 63(1): 210-247.

Zhou, K. Z., \& Wu, F. 2010. Technological capability, strategic flexibility, and product innovation. Strategic Management Journal, 31(5): 547-561.

\section{APPENDIX 1: AN EXAMPLE OF ICN AND IKN CONSTRUCTION}

Figure 2 displays an example of a patent's bibliographic information. We used the inventors' full names and affiliations to identify each unique inventor and considered collaboration ties only between two inventors who worked together on a project.

In Figure 3, the middle rows depict four patents and their inventors. For example, A, B, and C worked on the first patent, whereas $C$ and $D$ worked on the second patent. Co-inventors of the same patent constitute a fully-linked clique (e.g., A, B, and $C$ in patent 1 ), as shown in upper rows. Given 
CN103760333A Method for separating red blood cells in blood sample, and applications

$\longrightarrow$ Patent publication number

Bibliographic data Description Claims Drawings Original document Citations Legal events Patent family

$\begin{array}{ll}\text { Applicants } & \text { ABON BIOPHARM HANGZHOU CO LTD }+\longrightarrow \text { Firm name } \\ \text { Inventors } & \text { GAO FEI; LIU JIE; LIU YI; MA TIANYA; WU YINFEI }+\longrightarrow \text { Inventor name }\end{array}$

Classifications

IPC G01N33/531; G01N33/566; $\longrightarrow$ International patent classifications

CPC G01N33/5005 (CN); G01N33/566 (CN);

Priorities CN200910206522A-2009-10-13; CN201410006059A-2009-10-13

Application CN201410006059A-2009-10-13 $\longrightarrow$ Application date

Publication CN103760333A-2014-04-30

Figure 2 Bibliographic information of a patent.

that $\mathrm{C}$ worked on patents 1 and 2, we considered the first two cliques (i.e., $\mathrm{A}, \mathrm{B}$, and $\mathrm{C}$ and $\mathrm{C}$ and $\mathrm{D}$ ) further connected.

In Figure 3, the middle rows depict four patents, and the IPCs are involved in each patent. For instance, IPC 1 and IPC 2 are combined in the first patent, and IPC 2 and IPC 3 are combined in the second patent. In the bottom row (the IKN), IPC 1 and IPC 2 are linked. Moreover, IPC 2 is involved in patents 1 and 2, so IPC 1, IPC 2, and IPC 3 form a chain.

\section{APPENDIX 2: CALCULATION OF SMALL- WORLDNESS}

After constructing each subsidiary's ICNs and IKNs in each year, we calculated their small-world quotients and defined the clustering coefficient of node $j$ in a network as

$$
C_{j}=\frac{2 e_{j}}{k_{j}\left(k_{j}-1\right)},
$$

where $k_{j}$ is the number of node $j$ 's neighbors, and $e_{j}$ is the number of ties connecting them. For example, in Figure 3 , the clustering coefficient of inventor $A$ is $(2 \times 1) /[2 \times(2-1)]=1$. We calculated the clustering coefficient of the whole network of subsidiary $i$ as the average of this measure across all nodes in its network. For example, the clustering coefficient of the ICN in Figure 3 is (1/ 8) $\times(1+1+1 / 3+0+1 / 2+1+1+1)=0.729$.

We calculated the average shortest path of a subsidiary's whole network as

$$
L_{i}=\sum_{k \geq j} d_{k j} / \frac{1}{2} n(n-1),
$$

where $d_{k j}$ is the shortest path length between nodes $k$ and $j$, and $n$ is the number of vertices in the network. For example, in Figure 3, the shortest path length between inventors $A$ and $H$ is 4 (i.e., A-C-D$\mathrm{E}-\mathrm{H})$. The average shortest path measure of the ICN in Figure 3 is 2.214.

We identified small worlds in a network. Specifically, we used the ratios of clustering coefficient and average shortest path values to those of a baseline random network. A small-world structure shows a much larger clustering coefficient than its random counterparts but a roughly equal average shortest path length.

$$
Q_{i}=\alpha\left(C_{i} / C_{R-i}\right) / \beta\left(L_{i} / L_{R-i}\right),
$$

where $\alpha=1 / n$ and $\beta=\ln (n)$. We included $\alpha$ and $\beta$ in calculating size-adjusted ratios, as they can fully exclude the distorting effect of total network size. We took the ICN in Figure 3 as an example. $\alpha$ and $\beta$ 


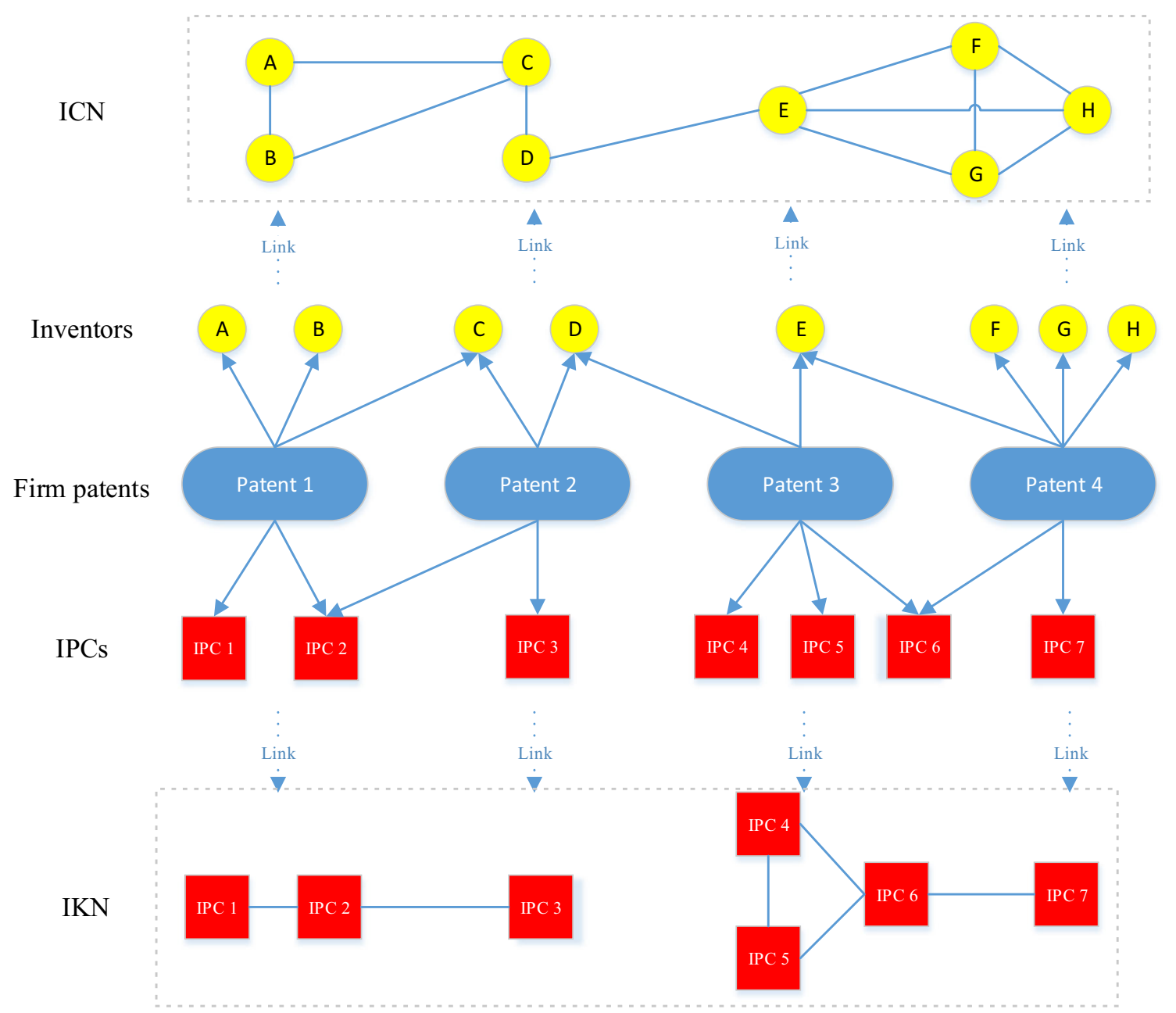

Figure 3 An example of constructing an ICN and an IKN.

are $1 / 8$ and $\ln (8)$, respectively. $C_{R-i}$ and $L_{R-i}$ are the characteristics of a random network with the same number of nodes and average degree. We approximated the random network's clustering coefficient and average shortest path length using $C_{R-i}=k / n$ and $L_{R-i}=\ln (n) / \ln (k)$, where $k$ refers to the average number of ties per node in an internal network. We took the ICN in Figure 3 as an example. $C_{R-i}$ and $L_{R-i}$ are $22 /\left(8^{*} 8\right)$ and $\ln (8) / \ln (22 / 8)$, and the small world quotient is 0.118 . On the basis of the above steps, we calculated a small-worldness index for each ICN and each IKN of each subsidiary in each year.

\section{ABOUT THE AUTHORS}

Yan Yan is a tenure-track Assistant Professor in School of Business, Renmin University of China. He received his $\mathrm{PhD}$ from the University of Groningen, Netherlands. His current research interests include innovation, network analysis, and IPR protection. He has published papers in journals such as Research Policy and IEEE Transactions on Engineering Management.

Jiatao Li is Chair Professor of Management, Lee Quo Wei Professor of Business, Director of the Center for Business Strategy and Innovation, and Senior Fellow of the Institute for Advanced Study, Hong Kong University of Science and Technology. He is a Fellow of the AIB and an editor of the Journal of International Business Studies. His research interests are in the areas of global strategy, innovation, entrepreneurship, corporate governance, and digital economy.

Jingjing Zhang is an Associate Professor at School of Public Policy and Management, University of Academy of Chinese Sciences. She received the PhD degree in Management from the University of 
Chinese Academy of Sciences, China. She was a Post-Doctoral Fellow in the Faculty of Economics and Business, University of Groningen, Netherlands. Her research interest is in innovation management, innovation network and public policy. She has published in scholarly journals such as Research Policy and Technological Forecasting and Social Change.

Open Access This work is licensed under a Creative Commons Attribution-NonCommercialNoDerivs 3.0 Unported License. The images or other third party material in this article are included in the articleã s Creative Commons license, unless indicated otherwise in the credit line; if the material is not included under the Creative Com-mons license, users will need to obtain permission from the license holder to reproduce the material. To view a copy of this license, visit http://creativecommons.org/licenses/ by-nc-nd/3.0/.

Publisher's Note Springer Nature remains neutral with regard to jurisdictional claims in published maps and institutional affiliations.

Accepted by Pervez Ghauri, Consulting Editor, 1 March 2021. This article has been with the authors for two revisions. 